\title{
THE RELATIONSHIP BETWEEN PERSONALITY TYPES AND REWARD PREFERENCES
}

\author{
Ronél Nienaber: Department of Industrial Psychology and People Management, \\ University of Johannesburg, South Africa \\ Mark H R Bussin: Department of Industrial Psychology and People Management, \\ University of Johannesburg, South Africa \\ Carolina Henn: Department of Industrial Psychology and People Management, \\ University of Johannesburg, South Africa
}

\begin{abstract}
Orientation: Research has shown that total rewards models structured according to individual preferences, positively influence efforts to attract, retain and motivate key employees. Yet, this is seldom done. Structuring total rewards models according to the preferences of employee segments is a viable alternative to accommodate individual preferences.
\end{abstract}

Research purpose: The primary aim of the study was to determine the relationship between personality types and reward preferences. The secondary aim was to determine the reward preferences for different demographic groups.

Motivation for the study: An enhanced understanding of reward preferences for different employee segments will enable employers to offer more competitive reward options to their employees. This may, in turn, have a positive impact on retention.

Research design, approach and method: Two measuring instruments, the MBTI® Form GRV and the Rewards Preferences Questionnaire, were distributed electronically to 5000 potential respondents. The results from 589 sets of questionnaires were used in the data analyses. Primary and secondary factor analyses were done on the items in the Rewards Preferences Questionnaire.

Main findings/results: The study confirmed that individuals with certain personality types and personality preferences, have different preferences for certain reward categories. There was a stronger relationship between reward preferences and personality preferences than for reward preferences and personality types. Preferences for reward categories by different demographic groups were confirmed. The significant difference in reward preferences between Black and White respondents in particular was noteworthy, with Black respondents indicating significantly higher mean scores for all reward categories than White respondents. Finally, a total rewards framework influenced by the most prominent preferences for reward categories, was designed.

Practical/Managerial implications: This study confirms that there are significant differences in the reward preferences of different segments. Management can more effectively structure reward models according to these preferences without increasing overall costs.

Contribution/value-add: The existing body of knowledge on the reward preferences of people with different personality types and personality preferences are enhanced. In addition, the study on the reward preferences of different demographic groups within a South African context adds considerably to the existing body of literature. Based on research results, a total rewards framework, on employee preferences, was designed. Furthermore, an increased understanding of the reward categories that contribute towards .the attraction, retention and motivation of employees as well as preferences for certain reward categories, have been obtained.

Key words: rewards management; total rewards model; motivation; retention; flexible reward practices. 


\section{INTRODUCTION}

\section{Key focus of the study}

A work environment characterised by a global shortage of key skills (Corporate Leadership Council, 2008); changing needs of employees (Claus, 2007; Grant Thornton, 2008); and more flexible reward practices (Abboud, 2007; Olson, Van Bever \& Verry, 2008) form the rationale for this study. Increasingly, employers realise that the core asset of the modern business enterprise does not lie in buildings and in investments, but in the intelligence, skills and experience of employees who need to be retained (Manville \& Ober cited in Harvard Business Review, 2003). The attraction and retention of employees continues to be a key priority for HR professionals (Frank, Finnegan \& Taylor, 2004; Giancola, 2008).

The workplace is becoming very complex for employers to manage and the talent shortage exacerbates the complexity. The apartheid policy in South Africa created racial segmentation in the labour market, the effect of which can still be seen even now in racially and gender based skills shortages. In addition, job reservation for white males and a comparatively lower level of skills training for black employees left a legacy of significant pay differentials between different race and gender groups, referred to as the apartheid wage gap (Horwitz, Browning, Jain \& Steenkamp, 2002). As a result of a labour shortage globally, skilled employees are in a position where they deliberately choose who they want to work for and for how long (Herman \& Gioia, 2000; Kaliprasad, 2006); they are also no longer restricted by traditional borders (Berger \& Berger, 2004).

Retention is critical for employers as it influences expenses on two levels, namely directly through staff turnover expenses (for example recruitment costs, lost productivity, training and development and lost opportunity costs) and indirectly through aspects such as engagement (Corporate Leadership Council, 2004). There is a high correlation between retention, engaged employees and financial sustainability of organisations (Bussin, 2008a; Bussin, 2008b; Deloitte, 2004; Schaufeli \& Enzmann, 1998).

One way in which organisations can respond to employee demands is by understanding the reward preferences of employees (Linkow, 2006). More specifically, there are many rewards other than pay that should be considered by management (Grant Thornton, 2008; Murlis, 1996). While Armstrong (2006) indicates that most employers do not have high levels of sensitivity towards the reward preferences of their employees, employees themselves, especially those with key skills, are becoming more demanding and require organisations to make exceptions on the basis of their individual preferences (Herman \& Gioia, 2000). Kaliprasad (2006) confirms that when management actively listens to the preferences of employees, this results in higher levels of motivation and engagement.

\section{Background to the study}

One solution to this dilemma is to address employee needs through a holistic, integrated and business-aligned approach to reward management. This total rewards strategy flows from the organisation's business and human resources strategies, and aligns to the organisational goals (Armstrong \& Thompson, 2002). The total rewards concept is multi-dimensional and developed from an array of different disciplines. The interest in reward practices has increased significantly over the past $10-15$ years, emanating from the initial basic understanding of pay and benefits to what is now commonly categorised into financial (also referred to as transactional or tangible rewards), and nonfinancial (also referred to as relational or intangible rewards) intrinsic and extrinsic rewards as part of a total rewards model (Du Toit, Erasmus \& Strydom, 2007; WorldatWork, 2007). Flexible reward models that can adapt to environmental, individual and organisational changes, is a critical lever to motivate, attract and retain talented employees and can positively influence productivity by up to $35 \%$ (Hill \& Tande, 2006; Lawler, 1990; Menefee \& Murphy, 2004).

There is a wide range of approaches to the development of total rewards models and frameworks. Despite differing opinions around the nomenclature used in the reward categories, and the categorisation thereof, the inherent meaning of the different categories is mostly similar. In addition, typically organisations arrive at their own definition of total rewards and brand it accordingly (Keuch, Chuang, May \& Sheldrake, 2006; Milkovich \& Newman, 1999). Based on an analysis of the literature (Armstrong \& Brown, 2006; Berger \& Berger, 2004; Corporate Leadership Council, 2008; Crawford \& Giowa, 2008; Gross \& Friedman, 2007; Herman \& Gioia, 2000; Lawler, 2000; Milkovich \& Newman, 1999; Towers Perrin, 2007 and Zingheim \& Schuster, 2007) a total rewards framework with 
underlying reward categories has been developed. This framework, depicted in Figure 1, encompasses all the key reward categories identified in the literature.

Figure 1: Categories of the theoretical total rewards framework

TOTAL REWARDS

\begin{abstract}
FINANCIAL REWARDS (ALSO REFERREDTOAS TOTAL PACKAGE)
\end{abstract}

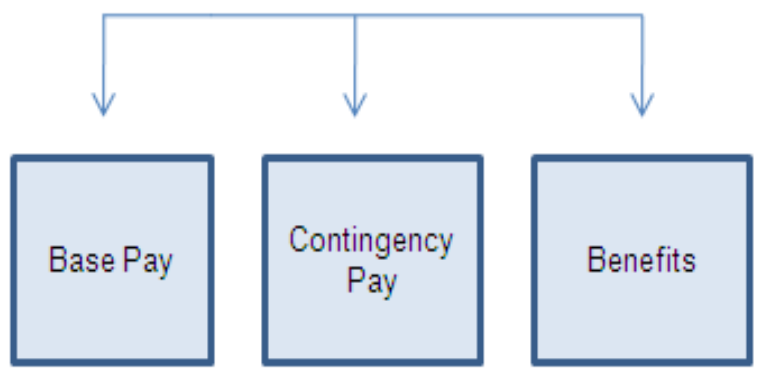

NON-FINANCIAL REWARDS

(ALSO REFERREDTOAS

ADDITIONAL REWARDS)

The categories shown in Figure 1, as well as the underlying reward components that make up the categories, play a critical role in the motivation and retention of employees (Hankin, 2005). Prevailingly, salary is still considered a major determinant of work motivation and appropriate work behaviours (Deci \& Ryan, 2000; Kohn cited in Harvard Business Review, 2001; Henderson, 2003). Yet, if an organisation focuses solely on remuneration, this may not be sufficient to sustain motivation or to retain key employees (Bergmann \& Scarpello, 2001). Organisations that incorporate financial and non-financial rewards are more likely to compete successfully in the global employment market (Gerhart \& Rynes, 2003; Stein, 2007).

\section{Trends from the research literature}

There is paucity of empirical research on the efficacy of different components of the total rewards model, especially within a South African context. Research conducted amongst employees in Europe and North America indicate that people have different reward preferences, that different categories of the rewards model have different value for employees and ultimately that understanding and responding to employee reward preferences drive commitment, engagement and retention (Armstrong \& Thompson, 2002; Corporate Leadership Council, 2002). In addition, employees working for one organisation but within different geographic locations such as China, Japan, Germany and the USA, have distinctly different reward preferences and motivators; and where rewards models are tailored according to cultural differences, the motivational effectiveness thereof increases (Chiang, 2005; Gunkel, 2006; MacGrain Herkenhoff, 2000; Rehu, Lusk \& Wolff, 2006).

Flexible total rewards models may sound appealing to many employees, but the reality is that for most organisations it is impossible to administer unique individualised reward requests due to the onerous administrative burden. A way of overcoming this difficulty is to segment the workforce and to structure reward models according to the preferences of different employee segments (Gross \& Edelsten, 2006). Workforce segmentation stems from marketing methodologies where customers are segmented in order to develop more effective marketing strategies. Examples of segmentation include personality types, gender, age, family size, or educational level (Du Toit et al., 2007). Total rewards models designed in accordance with the reward preferences of employee segments can have maximum impact at no additional or even lower cost (Harris \& Clements, 2007).

Personality is considered to be formed as a result of combined hereditary (genetic) and environmental factors, it is moderated by situational conditions and has a big impact on how people are motivated (Murphy, 2008; Robbins, Odendaal \& Roodt, 2003). Personality is typically described in terms of traits or types. Personality traits are characteristics exhibited in a large number of situations and are used to describe peoples' behaviour in different situations (Robbins et al., 2003). Traits are relatively stable 
and enduring aspects of individuals that distinguish them from other people (Martin, 2005). Personality type, on the other hand, refers to a combination of various personality traits and preferences (Myers, 1998). Personality types, in terms of Jungian theory (1971) refer to the mental functions involved in gathering information and making decisions on the basis of this information. Jung (1971) concludes that differences in behaviour result from peoples' inborn tendencies to use their minds in different ways. As people act on these tendencies, they develop predictable patterns of behaviour (McCaulley, 1998). When people differ systematically in what they perceive and in how they reach conclusions, this contributes to different interests, reactions, values, motivations and skills (Bayne, 2004). Jung further reasons that there are certain dimensions of psychological functioning namely:

a) Relating to other people: The two dimensions Introversion and Extraversion, refer to an orientation to either the inner world of ideas and feelings (I) or the outer world of people and objects (E). These two constructs refer to where individuals receive their energy from and how they distribute energy (Pearman \& Albritton, 1997).

b) Using information to make decisions refer to Thinkers who prefer to make decisions logically based on facts and figures and cause and effect analysis in contrast to Feelers who prefer to base decisions on more subjective information based on personal value and the relational impact of such decisions (Myers, 1998).

c) Gathering information are presented in two constructs namely Sensing and Intuition where individuals with a Sensing preference, prefer to concentrate on details using five senses to analyse sensory data. Intuitive individuals prefer to focus on the broader, big picture issues and have a preference to recognise relational, abstract data through intuition (CPP, 2008).

The Myers-Briggs Type $\AA$ Indicator, one of the most widely used personality assessment instruments used worldwide, has been designed in accordance with Jung's theory of personality types (CPP, 2008; DuBrin, 2005; Kroeger \& Thuesen, 1998; Reinhold, 2008). A fourth dimension that was added to the work started by Jung, is the orientation to the external world assessed through the constructs Judging and Perceiving (Pearman \& Albritton, 1997).

The eight personality preferences are clustered into four polar personality dimensions of Extraversion $(E)$ and Introversion (I), Sensing (S) and Intuition (N), Thinking (T) and Feeling (F) and Judging (J) and Perceiving $(\mathrm{P})$. Personality preferences are a popular way of interpreting behaviour and a combination of the personality preferences make up a psychological typology (Myers, 1998). The inherent different characteristics of the eight preferences, give rise to the uniqueness of personality types when these preferences are combined into 16 different types. The 16 different types are indicated in Table 1.

Table 1: MBTI® 16 personality types

\begin{tabular}{clllll}
\hline & \multicolumn{2}{l}{ Sensing Types } & \multicolumn{2}{l}{ Intuitive Types } \\
\hline \multirow{2}{*}{ Introvert } & Thinking & Feeling & Feeling & Thinking \\
& I-J & ISTJ & ISFJ & INFJ & INTJ \\
\multirow{3}{*}{ Extravert } & I-P & ISTP & ISFP & INFP & INTP \\
& E-P & ESTP & ESFP & ENFP & ENTP \\
& E-J & ESTJ & ESFJ & ENFJ & ENTJ \\
\hline
\end{tabular}

(adapted from Myers \& Myers, 1995) 
Jung believed that every individual develops a dominant type early on in life, which remains dominant, although it can change over time (Millner, 2008). The language used in the descriptors and the practical application of the typology, makes it a popular methodology in the workplace (Pearman \& Albritton, 1997).

The relationship between pay and personality traits has been the subject of past research. Findings showed that extraverts are more inclined to be motivated by money and introverts are more motivated by fear of punishment; conscientious people prefer equity (fair differentiation) over equality in reward systems (Furnham \& Argyle, 1998). A positive relationship between certain personality traits (extraversion, conscientiousness, aggression) and levels of earnings has also been confirmed as well as a correlation between gender and earnings (Bartlett, Grant \& Miller, 1990; Bowles, Gintis \& Osborne, 2001). The relationship between earnings levels and personality traits can partly be explained through the market value of certain personality traits as not all personality traits are equally productive or valued (Müller \& Plug, 2005). Westerman, Beekun, Daly and Vanka (2009) found a weak relationship between individual personality variables and pay package preferences. Gray (1973) reported that extraverts have a higher preference for variable pay due to their higher risk tolerance, and that they prefer open-plan office environments. Introverts, on the other hand, prefer quiet space to work (Cable \& Judge, 1993), More conscientious people have been found to have a greater need for learning and development opportunities and attach more value to an environment that is characterised by good social relationships (Stewart \& Barrick, 2004). Vandenberghe, St-Onge and Robineau (2008) contributed to previous studies by reporting that the prominence given to work prestige or job level correlates with the Five Factor Model (FFM) personality traits "openness to new experiences" and "extraversion".

Some initial research has been done on the relationship between personality temperaments and monetary spending patterns (Bayne, 2004; Kroeger \& Thuesen, 1988). The relationship between rewards and personalities has evoked interest among researchers for many years, yet limited empirical findings have been reported to date (Gerhart \& Rynes, 2003; Giancola, 2006a; Nyhus \& Pons, 2004). A total rewards framework does not necessarily influence performance but can be associated with higher levels of engagement, productivity, retention, a stronger employee value proposition and a positive influence on organisational performance (Frank et al., 2004; Gebauer, 2009). The influence is even more significant when the reward offering is designed in accordance with employee preferences (Butler \& Waldroop, 2004; Giancola, 2007; Sung \& Todd, 2004; Werhane, 2008). There are, however, limited research on the relationship between personality types and reward preferences which is surprising given the universal importance of money and the role that rewards play in the attraction and retention of employees.

\section{RESEARCH OBJECTIVES}

Given the limited available research on the relationship between personality types and reward preferences, this study aimed to answer the following research questions:

- What is the relationship between personality types and personality preferences (as defined by the MBTI instrument) and reward preferences?

- What influence do selected demographical variables have on reward preferences?

The next section covers the design of the study. Thereafter, the results will be presented followed by the discussion thereof.

\section{RESEARCH DESIGN}

\section{Research approach}

The research design was quantitative and exploratory relational. The research variables were defined as follows:

a) the independent variable was the employee's personality type as defined by the MBTI尺 instrument; and

b) the dependent variables were the categories and components that formed part of the total rewards model that were identified through the literature review, for example base salary, incentives, medical aid and career opportunities. 
Two questionnaires namely the MBTI® form GRV (GRV) and the Rewards Preferences Questionnaire (RPQ) were distributed electronically to respectively assess the respondents' personality types and preferences and, reward preferences. Demographic data was collected as part of the reward preferences questionnaire.

\section{RESEARCH METHOD}

\section{Research participants}

The measuring instruments were distributed electronically to 5,000 potential respondents extracted from the client listing of $21^{\text {st }}$ Century Business \& Pay Solutions the member list of the South African Reward Association, and Nedbank Group Ltd employees employed at its head office in Sandton, Johannesburg. As far as could be established, all respondents had internet access. Although convenience sampling was employed, the final sample was representative of a wide range of working people from different age, race and gender groups and different job levels. A total of 894 completed RPQs and 787 GRVs were captured on two separate servers. After the unique passwords from the different sets were compared, a dataset of 589 combined responses was used for data analyses purposes representing a response rate of $11.78 \%$ of the original targeted group of respondents.

The majority of respondents were women (59.6\%) and white (74.5\%). Most of the respondents $(49.2 \%)$ fell in the age group $18-38$ years, reported being married or living together $(69.8 \%)$ with either no children $(39.4 \%$ ) or more than two children $(36.3 \%)$. In addition, $40.4 \%$ of the respondents obtained a degree or diploma and $39.4 \%$ reported to have a post-graduate qualification. A large portion of the respondents $(36.7 \%)$ were employed in specialist or professional positions and the second largest grouping (25.3\%) were employed in senior management positions. In terms of completed years of service, $35.7 \%$ of the sample reported to have ten years or longer working experience with their current employer.

\section{Measuring instruments}

Two measuring instruments were used namely the Rewards Preferences Questionnaire (RPQ) (available from the authors on request) and the web-based MBTI® Form GRV (Global Research Version) questionnaire. The RPQ was informed by the theoretical total rewards framework (Figure 1 with additional underlying reward components) and tested on two pilot groups before finalisation thereof. A combination of nominal and ordinal, a seven-point Likert scale and a forced ranking scale were used in the three sections of the questionnaire. The MBTI® Form GRV has recently been made available by CPP, Inc and is a combination of the response items contained in Forms $M$ and $Q$ (CPP, 2008). Forms $M$ and $Q$ have been well researched and the psychometric properties thereof have been well established. Internal consistency, reliability and validity have been confirmed (Taylor \& Yiannakis, 2007; Taylor \& Yiannakis, 2009).

\section{Research procedure}

Responses to the two measuring instruments had to be captured and submitted in an electronic form. Respondents were requested to use the same unique password on both questionnaires in order to match their personality type with their reward preferences, whilst protecting anonymity. After the unique passwords were matched on the two sets of questionnaires, the results of 589 GRV and RPQ were used and the balance were discarded.

\section{Statistical analysis}

In order to reduce the dimensionality of the 46 items in the RPQ, factor analysed was used. The Kaiser-Meyer-Olkin measures of sampling adequacy (0.86) indicated that a factor analysis on the data would be useful as it exceeded the recommended value of 0.6. Bartlett's Test of Sphericity reached statistical significance $(p<0.05)$, supporting the factorability of the correlation matrix pertaining to the items in the questionnaire. A first-order factor analysis was done on the 46 items included in Section 2 of the Rewards Preferences Questionnaire. The principal axis factor extraction method was used with a Varimax rotation and Kaiser normalisation. The data reduction technique was applied by excluding items where the loadings on the initial and the extracted communalities were $<0.3$ (Pallant, 2007).

\section{RESULTS}


The study had a dual aim. The first research question was aimed at .determining the relationship between personality types and personality preferences (as defined by the MBTI® instrument) and reward preferences. The second research question aimed to determine the influence that selected demographical variables had on reward preferences.

\section{Factor Analysis}

Eight factors were extracted using the Kaiser criterion of eigenvalues $>1$. Eight factors, with eigenvalues $>1$, explained $65.33 \%$ of the variances. The eigenvalues are indicated in Table 2.

Table 2: Initial eigenvalues on First-Order Factor Analysis

\begin{tabular}{llll}
\hline \multicolumn{3}{l}{ Initial eigenvalues } \\
\hline Factor & Total & \% of Variance & Cumulative \% \\
\hline 1 & 7.743 & 25.809 & 25.809 \\
\hline 2 & 2.903 & 9.675 & 35.484 \\
\hline 3 & 2.185 & 7.284 & 42.768 \\
\hline 4 & 1.772 & 5.908 & 48.676 \\
\hline 5 & 1.419 & 4.731 & 53.407 \\
\hline 6 & 1.248 & 4.159 & 57.566 \\
\hline 7 & 1.185 & 3.948 & 61.514 \\
\hline 8 & 1.145 & 3.818 & 65.332 \\
\hline
\end{tabular}

Although the original eight factors would have been a closer resemblance to the reward categories identified in the theoretical total rewards framework, the large number of cross-loadings on the items and the small number of items loading on some of the first-order factors (for example factors 7 and 8), necessitated a second-order factor analysis. The principal axis factoring method with an oblique (correlated) rotation, namely Direct Oblimin, was used in the second-order factor analysis. From the original eight factors identified, two factors were extracted for the final total rewards framework by using the Kaiser criterion of eigenvalues $>1$. These factors explained $60.6 \%$ of the variances in the eight first-order factors (refer to Table 3).

Table 3: Eigenvalues on second-order factor analysis

\begin{tabular}{llll}
\multicolumn{4}{l}{ Eigenvalues } \\
\hline Factor & Total & \% of Variance & Imulative \% \\
\hline 1 & 3.790 & 47.369 & 47.369 \\
\hline 2 & 1.059 & 13.232 & 60.601 \\
\hline 3 & .785 & 9.816 & 70.417 \\
\hline 4 & .740 & 9.252 & 79.669 \\
\hline 5 & .650 & 8.119 & 87.788 \\
\hline 6 & .439 & 5.482 & 93.270 \\
\hline 7 & .364 & 4.552 & 97.823 \\
\hline 8 & .174 & 2.177 & 100.000 \\
\hline
\end{tabular}

Two factors were extracted from the second-order factor analysis. These two factors were labelled conducive working environment and remuneration and benefits. The two factors correlated highly with each other $(r=0.652)$.

In order to determine the reliability or internal consistency of each of the second-order factors, Cronbach Alpha's were subsequently calculated. The Cronbach Alpha was 0.878 on factor 1 and 0.862 on factor 2 which are both considered acceptable. 
Descriptive statistics were calculated on the composite results for the two factors. The results are reported in Table 5.

Table 5: Descriptive statistics for reward categories

\begin{tabular}{|c|c|c|c|c|c|c|c|c|c|}
\hline Reward Categor & ies & Mean & Median & SD & Min & Max & Range & $\begin{array}{l}\text { Skew } \\
\text { ness }\end{array}$ & Kurtosis \\
\hline $\begin{array}{l}\text { Factor } \\
\text { Conducive } \\
\text { working } \\
\text { environment }\end{array}$ & 1: & 5.4710 & 5.5333 & .83329 & 2.53 & 7.00 & 4.47 & -.409 & -.212 \\
\hline $\begin{array}{l}\text { Factor } \\
\text { Remuneration } \\
\text { benefits }\end{array}$ & 2: & 4.3681 & 4.4000 & .98873 & 1.73 & 7.00 & 5.27 & -.056 & -.310 \\
\hline
\end{tabular}

From Table 5 it can be seen that the reward category a conducive working environment had the highest combined mean score, indicating the highest preference for the items that make up this reward category compared to the remuneration and benefits category.

After the completion of the factor analysis, the reward components were accordingly clustered into the new reward categories. Table 6 sets out the reward categories and components in the empirical total rewards framework. The arrows indicate the interdepence of the financial and non-financial reward categories and that the reward components are not finite and can be added to.

Table 6: Categories and components in the empirical total rewards framework

\begin{tabular}{|c|c|}
\hline NON-FINANCIAL REWARDS & FINANCIAL REWARDS \\
\hline A conducive working environment & Remuneration and benefits \\
\hline A good working relationship with colleagues & Salary or guaranteed remuneration \\
\hline Quality co-workers in the team & Annual performance bonus \\
\hline Personal safety in the workplace & Medical aid benefits \\
\hline $\begin{array}{l}\begin{array}{l}\text { Constructive } \\
\text { performance }\end{array} \\
\text { and honest feedback }\end{array}$ & Retirement and disability benefits \\
\hline $\begin{array}{l}\text { Monthly communication sessions about } \\
\text { business progress }\end{array}$ & $\begin{array}{l}\text { Increases linked to inflation, not } \\
\text { personal performance }\end{array}$ \\
\hline $\begin{array}{l}\text { A balanced scorecard or agreed performance } \\
\text { objectives }\end{array}$ & $\begin{array}{l}\text { Phased in return from maternity or } \\
\text { paternity leave }\end{array}$ \\
\hline A comfortable working environment & On-site medical centre \\
\hline Informal recognition & On-site fitness centre \\
\hline Study leave & On-site convenience store \\
\hline $\begin{array}{l}\text { Growth opportunities, learning } \\
\text { development }\end{array}$ & On-site staff restaurant \\
\hline Bursaries for tertiary education & $\begin{array}{l}\text { On-site or subsided childcare } \\
\text { facilities }\end{array}$ \\
\hline Rotation to different jobs & Subsidised tuition for children \\
\hline & $\begin{array}{l}\text { Subsidy for financially dependent } \\
\text { parents }\end{array}$ \\
\hline & $\begin{array}{l}\text { Financial assistance to buy a } \\
\text { house }\end{array}$ \\
\hline
\end{tabular}

\section{PERSONALITY TYPES AND REWARD PREFERENCES}

In terms of the distribution of personality types, ISTJ was the most prevalent personality type (19.5\%) and ESTJ the second most prevalent type $(9.8 \%)$. In six of the personality types, the sample size was less than 30 of which three were less than 20 . It was decided that the types for which fewer than 20 responses were received, would be excluded from the analysis namely ENFJ, ISFP and INFJ as the 
sample sizes were considered to small to conduct meaningful analysis. Therefore, 13 personality types were used in the analysis of the data.

In order to investigate whether there are differences or similarities between the mean scores on each of the reward categories in terms of the 13 personality types, a two-way between-groups analysis of variance was conducted. Table 7 presents the result of the two-way ANOVA. Statistically significant differences were found between personality types in respect of both reward categories.

Table 7: Two-way ANOVA statistics

\begin{tabular}{|c|c|c|c|c|c|c|}
\hline Reward categories & & $\begin{array}{l}\text { Sum of } \\
\text { squares }\end{array}$ & df & $\begin{array}{l}\text { Mean } \\
\text { Square }\end{array}$ & $\mathbf{F}$ & $\mathbf{p}$ \\
\hline \multicolumn{7}{|l|}{ Importance of: } \\
\hline \multirow[t]{3}{*}{$\begin{array}{l}\text { A conducive working } \\
\text { environment }\end{array}$} & Between groups & 28.395 & 15 & 1.893 & 2.851 & $0.000^{*}$ \\
\hline & Within groups & 380.491 & 573 & 0.664 & & \\
\hline & Total & 408.886 & 588 & & & \\
\hline \multirow[t]{3}{*}{$\begin{array}{l}\text { Remuneration \& } \\
\text { Benefits }\end{array}$} & Between groups & 43.201 & 15 & 2.88 & 3.105 & $0.000^{*}$ \\
\hline & Within groups & 531.566 & 573 & 0.928 & & \\
\hline & Total & 574.768 & 588 & & & \\
\hline
\end{tabular}

To identify which personality types differed significantly from one another, the Scheffe post hoc test was performed. A summary of the post hoc comparison test results is shown in Table 8.

Table 8: Summary Results of Multiple Comparisons using Post hoc tests

\begin{tabular}{|c|c|c|c|c|}
\hline $\begin{array}{l}\text { Reward } \\
\text { Category* }\end{array}$ & $\begin{array}{l}\text { Wholy } 4 \text { letter } \\
\text { type (I) }\end{array}$ & $\begin{array}{l}\text { Wholy } 4 \\
\text { letter type (I) }\end{array}$ & $\begin{array}{l}\text { Mean } \\
\text { Difference (I- } \\
\text { J) }\end{array}$ & Sig. \\
\hline \multirow{7}{*}{1} & \multirow{6}{*}{ ESFP } & ESTJ & 0.708 & 0.000 \\
\hline & & INFP & 0.860 & 0.000 \\
\hline & & INTP & 0.794 & 0.000 \\
\hline & & ISTJ & 0.701 & 0.000 \\
\hline & & ISFJ & 0.660 & 0.031 \\
\hline & & INTJ & 0.728 & 0.032 \\
\hline & ESFJ & INFP & 0.733 & 0.027 \\
\hline \multirow{7}{*}{2} & \multirow{3}{*}{ ESFJ } & INTP & 1.045 & 0.001 \\
\hline & & ISTJ & 0.783 & 0.013 \\
\hline & & INFJ & 0.956 & 0.012 \\
\hline & \multirow{4}{*}{ ESFP } & INTP & 1.131 & 0.000 \\
\hline & & ENTP & 0.853 & 0.029 \\
\hline & & ISTJ & 0.868 & 0.006 \\
\hline & & INFJ & 1.042 & 0.006 \\
\hline
\end{tabular}

${ }^{*}$ Reward Category 1: A conducive working environment

Reward Category 2: Remuneration and Benefits 
Table 8 indicates that a number of statistically significant differences were present in the reward preferences of different personality types. Post hoc comparisons indicated that in respect of the reward category conducive working environment (reward category 1 ), the mean preference score for personality type ESFP $(M=6.03, S D=0.46)$ was significantly different for personality types ESTJ $(M$ $=5.33, S D=0.76)$, INFP $(M=5.17, S D=0.71)$, INTP $(M=5.24, S D=0.78)$, ISTJ $(M=5.33, S D=$ $0.89)$, ISFJ $(M=5.38, S D=0.80)$ and INTJ $(M=5.31, S D=0.96)$. The mean preference score for personality type ESFJ $(M=5.91, S D=0.77)$ was significantly different from the mean preference score for personality type INFP $(M=5.17, S D=0.71)$.

In respect of reward category two, remuneration and benefits, the mean preference score for personality type ESFJ $(M=4.98, S D=0.90)$ was significantly different for personality type INTP $(M=$ 3.93, $S D=0.88)$, ISTJ $(M=4.20, S D=1.02)$ and INFJ $(M=4.02, S D=0.51)$. In addition, the mean preference score for personality type ESFP $(M=5.06, S D=0.84)$ was significantly different from the mean preference scores reported for personality types INTP $(M=3.93, S D=0.88)$, ENTP $(M=4.21$, $S D=0.95)$, ISTJ $(M=4.20, S D=1.02)$ and INFJ $(M=4.02, S D=0.51)$.

\section{PERSONALITY PREFERENCES AND REWARD PREFERENCES}

A secondary analysis was conducted on the dataset where the relationship between personality preference and reward preferences was explored.

Statistically significant mean differences were observed in respect of preferences for both reward categories and some of the personality preferences. The personality preferences are indicated on eight dimensions, namely sensing vs intuition, thinking vs feeling, extraversion vs introversion and judging vs perceiving. Paired-samples t-tests were conducted to evaluate whether respondents with different personality preferences have statistically significant different mean preferences for the reward categories. The findings of the t-tests are indicated in Table 9.

Table 9: Paired-sample t-tests

\begin{tabular}{|l|l|l|l|l|}
\hline \multicolumn{5}{|l|}{ Personality preferences } \\
\hline $\begin{array}{l}\text { Reward } \\
\text { categories* }\end{array}$ & E - I & S - N & T - F & J - P \\
\hline 1. & E (5.627) and & - & T (5.414) and & - \\
& I (5.328) & & F (5.572) & \\
\hline 2. & E (4.521) and & S (4.449) and & T (4.256) and & - \\
I (4.225) & N (4.254) & F (4.570) & \\
\hline
\end{tabular}

* Reward category 1: A conducive working environment

Reward category 2: Remuneration and benefits

There were statistically significant mean differences between respondents with a preference for extraversion in respect of both reward categories. In both reward categories these respondents indicated a higher composite mean score than the respondents with a preference for introversion.

\section{Reward preferences of different demographic groups}

The reward preferences of respondents in accordance with different demographic variables were analysed. Table 10 presents a synopsis of these results.

Table 10: Statistically significant mean differences observed in terms of reward preferences indicated by different demographic groups

\begin{tabular}{|l|l|l|l|l|l|l|}
\hline & \multicolumn{5}{|l|}{ Demographic groups } \\
\hline $\begin{array}{l}\text { Reward } \\
\text { catego- }\end{array}$ & Gender & Race & Age & $\begin{array}{l}\text { Educational } \\
\text { qualification }\end{array}$ & Tenure & Job level \\
\hline
\end{tabular}




\begin{tabular}{|c|c|c|c|c|c|c|}
\hline ries* & & & & & & \\
\hline 1 & \multirow{2}{*}{$\begin{array}{l}\text { Women } \\
\text { indicated } \\
\text { higher } \\
\text { preferen- } \\
\text { ce for } \\
\text { both } \\
\text { reward } \\
\text { cate- } \\
\text { gories }\end{array}$} & \multirow{2}{*}{$\begin{array}{l}\text { Black } \\
\text { respondents } \\
\text { indicated a } \\
\text { higher } \\
\text { preference } \\
\text { for both } \\
\text { reward cate- } \\
\text { gories }\end{array}$} & \multirow{2}{*}{$\begin{array}{l}\text { The older } \\
\text { the respon- } \\
\text { dents, the } \\
\text { lower the } \\
\text { preference } \\
\text { for both } \\
\text { categories }\end{array}$} & & $\begin{array}{l}\text { Respondents } \\
\text { with } 0-2 \\
\text { years had a } \\
\text { higher } \\
\text { preference } \\
\text { than those } \\
\text { with } 3-6 \\
\text { years' } \\
\text { service for } \\
\text { reward } \\
\text { category } 1\end{array}$ & \multirow{2}{*}{$\begin{array}{l}\text { The more } \\
\text { senior the } \\
\text { job level, } \\
\text { the lower } \\
\text { the prefe- } \\
\text { rence for } \\
\text { both reward } \\
\text { categories }\end{array}$} \\
\hline 2 & & & & $\begin{array}{l}\text { The higher the } \\
\text { qualifications } \\
\text { the lower the } \\
\text { preference for } \\
\text { reward } \\
\text { category } 2\end{array}$ & & \\
\hline
\end{tabular}

Note: Reward category 1: A conducive working environment

Reward category 2: Remuneration and benefits

\section{DISCUSSION}

The primary purpose of this study was to determine whether personality type and personality preference predict reward preferences of different employee segments. A secondary aim was to determine the influence of demographic factors on reward preferences.

\section{The influence of personality type on reward preferences}

In terms of reward category one, a conducive working environment, respondents with a preference for personality type ESFP indicated a statistically significant higher mean score than respondents in personality types ESTJ, INFP, INTP, ISTJ, ISFJ and INTJ. Respondents with a preference for personality type ESFJ scored a significantly higher mean score than respondents with a preference for personality type INFP. In terms of reward category two, remuneration and benefits, respondents with a preference for personality type ESFP reported a statistically significant higher mean score than respondents with a preference for personality type INTP, ENTP, ISTJ and INFJ. In addition, respondents with a preference for personality type ESFJ reported a significantly higher mean score than respondents with a personality preference INTP, ISTJ and INFJ.

Respondents with a preference for personality type ESFP reported the highest mean scores on both reward categories, respondents with a preference for personality type ESFJ reported the second highest mean score on both reward categories and respondents with a preference for personality type ENFJ reported the third highest mean score for both reward categories. Personality types INFP and INTP reported some of the lowest mean scores on both categories. The highest mean preference scores were reported on both reward categories by individuals with a personality preference for sensing (S) and for extraversion (E) and the lowest mean preference scores by individuals who appear to have a preference for intuition (N) and introversion (I).

Personality types ESFP, ESFJ and ENFJ all have in common a high need for others, for harmony and a preference for being in a position to help develop others. People with these preferences are excellent team players and keen observers of human behaviour (Myers, 1998). The preference for extraversion $(E)$ indicates that they receive their energy from other people and enjoy being among people, communicate through talking, are sociable and expressive and readily take the initiative (Myers \& Myers, 1995). The feeling $(\mathbf{F})$ aspect in all three identified types is often described as being accepting, trusting of emotions, fair-minded and seeking of consensus (Pearman \& Albritton, 1997). People with this personality preference are often seen as personal, being more interested in people than in things. extraverted feeling (EF) types value harmonious human contact above all other things, are conscientious, persevering and anxious to perform (Myers \& Myers, 1995). The common descriptors of these personality preferences are in support of the highest mean preference scores 
observed for personality types ESFP, ESFJ and ENFJ in the reward category a conducive working environment, compared to the other personality types.

More specifically, the personality type ESFP indicated the highest mean preference score for $a$ conducive working environment, which is indicative of people who enjoy satisfying careers, where their natural warmth, attention to detail, emphasis on interpersonal values and adaptability are valued. They are excited by continuous involvement in new activities and new relationships (Martin, 2005). Included in this reward category is a good working relationship, monthly communication sessions, performance management, goal-setting and regular feedback that would all be important considerations for people with a preference for ESFP. However, too much structure can be stifling and therefore the way in which performance is being managed should be discussed with these individuals to ensure that they are managed in the most optimal and effective manner without leading to levels of frustration (Myers et al., 1998). The survey result indicating that personality type ESFP has the highest preference for a conducive working environment can therefore be substantiated by the common descriptors available for this personality type.

On the other side of the dichotomy, people with a preference for personality type INTJ, INFP and INTP indicated the lowest mean preference scores for reward category one, a conducive working environment. One of the common personality preferences in these personality types, is introversion (I). The preference for introversion (I) is described as the process whereby people charge their batteries (away from others) and for the Introvert this is through a process of reflection. People with this personality preference are therefore less likely to feel the need to externalise their thoughts until they have to communicate with others (Pearman \& Albritton, 1997). Employees with a tendency towards introversion (I), are thus likely to be content working on their own. The personal interaction that may be implicit in a conducive working environment (such as team work and quality interaction with colleagues) may thus be of lesser importance to individuals with a preference for introversion (I) (Myers \& Myers, 1995).

A significant mean difference in the preference for a conducive working environment was observed between the personality types ESFP $(M=6.03)$ and INFP $(M=5.17)$. The descriptors for the preference INFP include that these people are best at individual work involving personal values (for example art, social sciences, writing, psychology and counselling) (Myers et al., 1998). They have a strong sense of duty and faithfulness, but no desire to influence other people (Myers \& Myers, 1995). Given the fact that a conducive working environment involves interaction with others through various processes, it is understandable that employees with a preference for INFP will have a lesser preference for this reward category to those with a preference for ESFP.

A significant mean preference difference was observed between personality types ESFJ $(M=5.91)$ and INFP $(M=5.17)$ for reward category one being a conducive working environment. The descriptors for the INFP personality type have already been discussed. The descriptors for personality type ESFJ are very similar to those for ESFP (who indicated the highest mean preference score). According to Myers, McCauley, Quenk and Hammer (1998), ESFJs often find themselves in careers that are characterised by a great deal of communication, nurturance and people-orientated work. They find themselves less often in positions where there is low contact with people. These characteristics explain the relatively higher preference for this reward category.

It is important to note though, that the mean preference scores for the reward categories were high for personality preferences extraversion (E) and introversion (I). This suggests that a conducive working environment and remuneration and benefits, although not unimportant for those with a preference for introversion (I), are of lesser importance for them than for those with a preference for extraversion (E). The two personality types that indicated the highest and lowest mean preference scores for the reward category remuneration and benefits are the same as for category one, namely ESFJ and ESFP (highest) and INFP and INTP (lowest), respectively.

\section{The influence of personality preferences on reward preferences}

The eight personality preferences (extraversion - introversion, sensing - intuition, thinking - feeling and judging - perceiving) of which a combination of four personality preferences make up a personality type, can individually also provide interesting insights into reward preferences. In respect of both reward categories, respondents with a personality preference for extraversion (E) indicated higher mean preference scores than respondents with a personality preference for introversion (I). 
The question is whether these respondents truly have a higher preference for the reward categories compared to respondents with a preference for introversion (I), or whether they are just more expressive and thus bound to indicate relatively higher preferences. According to Myers and Myers (1995), the present Western civilisation is dominated by people with a preference for extraversion (E). Extraverted (E) people are more vocal and typically make themselves known to a wide circle of people, multiply relationships and broaden their sphere of work. Extraverts $(E)$ need people around them to function optimally (Pearman, \& Albritton, 1997). Gray (1973) postulates that extraverts (E) are more inclined to be motivated by money, and generally prefer incentive schemes, as they have a higher propensity for risk-taking. Given the previous research and the descriptions, it is more likely that extraverts (E) in fact do have a higher preference for the two reward categories, in comparison to the introverts (I), and that the higher preference results were not as a result of a potential response bias towards choosing higher response categories.

Statistically significant mean preference differences were observed in respect of respondents with a personality preference for sensing $(\mathbf{S})$ and intuition $(\mathbf{N})$ in respect of the reward category remuneration and benefits, where respondents with a personality preference for sensing (S) reported the highest mean preference score. People with a preference for sensing (S) are primarily interested in actualities, and people with a preference for intuition (N) are mainly interested in possibilities (Myers \& Myers, 1995). People with a preference for sensing (S) are furthermore described as being sequential, factual and present, with a practical and realistic perspective (Martin, 2005). Sensing (S) individuals prefer to concentrate on the details and have a preference for using sensory data through the use of their senses (Myers \& Myers, 1995). These are all factors that support with the higher mean preference for remuneration and benefits, as they would prefer to reduce risk-taking and receive guaranteed benefits and opportunities. They enjoy more tangible things and thus would need to know what their remuneration and benefits in detail would entail. People with a sensing (S) preference appear to be better planners and more structured in their thinking compared to people with a preference for intuition (N) and would use the processes and products available under the remuneration and benefit category to plan for their personal needs.

The lower mean preference score observed for respondents with a personality preference intuition (N) fits well with the existing descriptors, namely to follow their own inspirations, their head-in-theclouds approach, being imaginative, unconventional, intellectual and having a general preference for change and new ways of doing things (Pearman \& Albritton, 1997). Intuitive (N) individuals require more flexibility, have a preference for recognising relational, abstract data through intuition (CPP, 2008; Kroeger \& Thuesen, 1988) and thus could have a reduced need for the specific details that relate to guaranteed remuneration and benefit structures per se and thus could explain the relatively lower mean preference score observed in respect to the reward categories.

Statistically significant mean preference differences were observed for respondents with a personality preference for thinking $(T)$ and feeling $(F)$ in respect of both reward categories. According to Pearman and Albritton (1997) people with a preference for thinking (T) are pulled towards an analytical, cause-and-effect type of judgement and people with a preference for feeling (F) are pulled towards a values-oriented, accommodating type of judgement. For both of the reward categories, the respondents with a personality preference for feeling $(\mathbf{F})$ reported significantly higher mean scores in comparison to respondents with a personality preference for thinking $(\mathrm{T})$. People with a personality preference for feeling (F) are typically described as subjective, fair-minded and humane. They seek harmony, appreciate people, have social values and are empathetic (Kroeger \& Thuesen, 1988).

The effect that decisions have on people is an extremely important component of the final decision reached and typically decisions taken are done with interpersonal involvement. This description stands in contrast to people with a preference for thinking (T), who tend to be more objective, firmminded, policy-driven and detached, and who tend not to get involved personally when decisions are made. Myers and Myers (1995) furthermore state that the TF preference is the only preference that shows a marked difference between men and women, with the majority of women having a preference for feeling (F). This is in alignment with the results obtained for the secondary research questions which found that women had significantly higher mean scores on both reward categories than men. The descriptors for people with a personality preference for feeling (F) aligns with the higher mean preference for the reward category a conducive working environment, as it supports their need to be accepted and be accepting, their acute awareness of the intricacies of networks, their urge for consistency with personal values and their seeking of consensus (Pearman \& Albritton, 1997). 
The fact that statistically significant mean preference differences were observed for both reward categories confirmed that, although respondents have different preferences for reward categories, all preferences were relatively high. The importance of a combination of monetary and non-monetary rewards in the total rewards offering cannot be underestimated, and the one reward category should not be offered in isolation or substitution of the other. Rewards should be appropriately linked to performance indicators that reflect an employee's input and competence. The extent to which monetary rewards are offered in relation to other types of rewards should be designed in accordance with employee preferences in order to increase their effectiveness.

\section{The influence of demographic variables on reward preferences}

This study confirms that reward preferences differ in terms of certain demographic factors - for example, race, number of children, age, educational qualifications, job level, years of service, marital status and gender. These differences are described in more detail in the next section.

\section{The influence of race on reward preferences}

In both reward categories, responses from African, Indian and Coloured respondents were collapsed into one category referred to as 'Black'. The responses from Black respondents indicated significantly higher mean preference scores than the White respondents in both reward categories. Hofstede (1980), MacGain Herkenhoff (2000) and Westerman et al. (2009), confirmed that national culture has an influence on reward preferences. In addition, the South African legacy of apartheid significantly contributed to the skills shortages that are being experienced and the earnings differentials that are still very apparent despite having a democratic society for 16 years - a history which could also influence reward preferences (Horwitz, et al., 2002). It is thus not surprising that similar findings were obtained in South Africa, given the diverse cultures in the country. Although the Black respondents have stronger mean preferences for both reward categories, it does not necessarily indicate that the preference for the respective reward categories is less for White respondents. In research conducted by Taylor and Yiannakis (2009), Black respondents scored higher on the expressive-contained facet scale (in the direction of expressive), compared to the White respondents. In line with these findings, it is possible that Black respondents are more expressive in stating their preferences. In addition, a history marked by marginalisation (Horwitz et al., 2002; Thomas, 2002) could also potentially explain why Black respondents who are now finally being offered equal opportunities, are more assertive and expressive in stating their reward preferences. These feelings could also extend beyond reward preferences to broader employment practices.

\section{The influence of age on reward preferences}

Statistically significant mean differences were present in respect of all age groups, in terms of both reward categories. For both reward categories, the respondents in the age group 18 years -38 years indicated the highest mean preference score and the mean preference score progressively lowered as the respondents got older. Research indicates that the differences in reward preferences are not necessarily related to the different generations but instead to life stage and age rather than the specific period or time of birth (Rehm, 2006). The assumption can therefore be made that reward categories such as remuneration and benefits and a conducive working environment are much more important to the younger employees, and reduce in need as employees get older.

\section{The influence of educational qualifications on reward preferences}

In terms of preferences for the reward category remuneration and benefits, statistically significant mean differences were observed for respondents with a matric qualification, respondents with a degree/diploma as their highest qualification and respondents with a postgraduate qualification. In all cases, the lower the level of educational qualification, the higher the mean preference score. These results coincide with the analysis between reward preferences and age: the older the respondents, the lower their preference for the reward categories. In relation to job level: the higher the job level, the lower the mean preference for the reward categories.

It is possible that employees with a postgraduate qualification could already be earning at a level of remuneration that they find satisfactory. They may also feel more secure in the knowledge that they are earning a market-related salary due to their level of education. The earnings potential of people with no post-matric formal qualification is also substantially less than for employees with post-matric 
formal qualifications, and especially post-graduate qualifications. Respondents with a matric qualification probably therefore earn less than their graduate counterparts, and this may explain the trend for a higher preference for remuneration and benefits. In addition, the higher the qualification, the greater the ability of an individual to influence his or her own salary (i.e. through negotiation or jobhopping). In terms of Maslow's hierarchy (1943), a basic need (such as salary) can be expected to be rated of higher importance than a conducive working environment, for those who are earning lower salaries.

\section{The influence of job level on reward preferences}

This study has shown that in both reward categories, statistically significant mean differences were observed in the reward preferences for respondents who are on different hierarchical levels within organisations. It was evident from the research that the higher employees move up the organisational hierarchy, the lower the mean preference for both reward categories. This is possibly because the higher an employee moves up the organisational hierarchy, the higher their earnings and the more influence they have over ensuring a conducive work environment for themselves. The findings in terms of age may thus be an artefact of older respondents occupying higher job levels. In terms of the reward category a conducive working environment, the difference in mean preference was significant for employees employed at an administrative level in comparison to senior and executive management as well as between junior management, senior and executive management. No statistically significant mean preference differences were observed between respondents in specialist/professional levels and other job levels.

In terms of the reward category remuneration and benefits, significant mean differences were observed in respect of most of the job levels. In all cases, the lower levels in the organisation, namely administrative and junior management levels, indicated significantly higher preferences for this reward category compared to senior and executive management. This trend mirrored what was observed in respect of age groups and educational qualifications and are possibly all related to each other.

\section{The influence of service on reward preferences}

Statistically significant mean differences were observed for respondents with $0-2$ years' service and those with 3-6 years' service, in terms of their preference for a conducive working environment. The longer employees are employed by an organisation, the weaker their preference for this reward category, as was also seen with the analysis of age differences. One would expect that employees who are new to the organisation would feel less confident about their ability to integrate with their working environment, or be accepted by their new teams, colleagues and their line manager compared to employees with much longer service, and therefore would report a stronger preference. Locke and Latham (2002) state that individuals experience a higher level of motivation, which results in better performance - if specific performance objectives have been agreed. The matters of goalsetting and performance management are both addressed by the reward category a conducive working environment, and employees who are new to an organisation would then have an even greater need for joint goal-setting than longer-serving employees. It is thus important to ensure that employees with the higher preference for a conducive working environment are on-boarded properly, that includes the setting of goals to ensure that they are productive very soon after joining the organisation, and more inclined to stay.

\section{The influence of gender on reward preferences}

Statistically significant mean preference differences were observed for men and women, in respect of both reward categories. The mean scores were significantly higher for women than for men. Women thus have a stronger preference for both remuneration and benefits and a conducive working environment. Earning differential studies between men and women have often indicated that men earn higher salaries than women in comparable positions (Müller \& Plug, 2005). This could be as a result of many women interrupting their careers during their child-bearing years - a gap in tenure that has proven to be very hard to overcome in later years when women resume their careers (Keenan, 2004). As women are increasingly entering the workplace on an equal basis with their male counterparts their preferences and earnings potential will have to be recognised and acknowledged (Grbich, 1994). Women, who were also marginalised in the past (Booysen \& Nkomo, 2010; Meulders, Plasman \& Rycx, 2004), may therefore indicate a stronger preference similar to what was found with the Black respondents if previous marginalisation influences reward preferences. The stronger preference that was found for a conducive working environment can be indicative of women having to fulfil multiple roles and therefore requiring a more flexible and supporting working environment to 
meet all these demands. In recognising the different preferences, more flexible reward structures could be made available to women in the workplace, assisting with their role as primary caregiver of their children in addition to professional positions held.

\section{In summary, the main results obtained in this study are:}

a) The relationships between personality types, personality preferences and their reward preferences were confirmed;

b) The reward preferences of different demographic groups were confirmed

c) A total rewards framework was designed integrating the most prevalent reward preferences of respondents in terms of the different reward categories.

Overall the study confirmed that there are significant differences in reward preferences of employees. Rewards should expand beyond monetary rewards to also include non-financial rewards and be tailored to meet individual preferences. The findings of this research are expected to assist particularly South African managers, human resources and rewards professionals in having a better understanding of reward preferences of different employee segments. Differentiating in reward offerings contribute to higher levels of attraction, retention, engagement and motivation that positively influence organisational performance.

\section{LIMITATIONS OF THIS RESEARCH}

The following aspects are viewed to be potentially limiting in terms of this study:

- The relatively lower number of respondents on Form GRV®, especially in analysing the type results where the samples for some of the types were below twenty;

- $\quad$ The respondents could not be identified in terms of the industries they present and it is possible that the results could be skewed in favour of rewards preferences of individuals working within the financial services industry;

- The relatively low numbers of Black respondents should be considered when the results are generalised.

\section{SUGGESTIONS FOR FUTURE RESEARCH}

The following suggestions are made in terms of future research within this field:

- $\quad$ Analysing the reasons why such significant differences were found in the reward preferences of White and Black respondents specifically; and

- Conducting a conjoint analysis on understanding the relative importance of the rewards categories, namely if people have to choose between different reward categories, which ones they would prefer.

This study confirms that reward offerings should firstly be diverse and not only contain monetary rewards and secondly, be tailored to meet individual preferences. Total rewards frameworks can also be designed in accordance with the preferences of different employee segments. The challenge is therefore to design pay practices that will support sound management practices and aid in the achievement of business goals by motivating employees to perform at continuously high levels. The key to attracting and retaining the best employees lies in an enriched, diversified total rewards framework that is an essential building block in the employee value proposition.

\section{REFERENCES}

Abboud, S. (2007). Best Buy uses flexibility and choice to improve long term incentive design. Workspan, 10/07:33. Scottsdale, United States: WorldatWork Press.

American Psychological Association (n.d.). Personality. Available from http://www.apa.org/topics/personality/index.aspx. (Accessed 10 January 2010).

Armstrong, M. \& Brown, D. (2006). Strategic Reward Making it Happen. USA: Kogan Page Limited. 
Armstrong, M. \& Thompson, P. (2002, July). A Guide To Total Reward: Part 1. E-Reward.co.uk. research report. E-Reward Fact Sheets, no. 2. Available from http://www.sara.co.za. (Accessed 10 October 2007).

Armstrong, M. (2006). A Handbook of Human Resource Management Practice. $10^{\text {th }}$ edition. United Kingdom: Cambridge University Press.

Bartlett, R.L., Grant, J.H. \& Miller, T.I. (1990). Personality differences and executive compensation. Eastern Economic Journal, 16(3):187:195.

Bayne, R. (2004). Psychological Types At Work: An MBTI® perspective. United Kingdom: TJ International, Padstow, Cornwall.

Berger, L.A. \& Berger, D.R. (2004). The Talent Management Handbook. United States: The McGraw Hill Companies.

Bergmann, T.J. \& Scarpello, V.G. (2001). Compensation Decision Making. 4th edition. USA: Harcourt, Inc.

Booysen, L.A.E. \& Nkomo, S.M. (2010). Gender role stereotypes and requisite management characteristics. The case of South Africa. Gender in Management: An International Journal, $3(4): 285: 300$.

Bowles, S., Gintis, H. \& Osborne, M. (2001, May). Incentive-enhancing preferences: Personality, behaviour and earnings. American Economic Association.

Burchman, S., Jones, B. \& Tourney, D. (2007). Compensation discussion \& analysis: lessons learned. Workspan, 05/07:90:97. Scottsdale, United States: WorldatWork Press.

Bussin, M. (2008a, May). Smart retention strategies, part 1. HR Future, 05/2008:13.

Bussin, M. (2008b, June). Smart retention strategies, part 2. HR Future, 06/2008:12:13.

Butler, T. \& Waldroop, J. (2004, June). "People” People. Harvard Business review:78:86.

Cable, D.M. \& Judge, T.A. (1993). Effects of Compensation systems on job search decisions: An application of person-organisation fit. Centre for Advanced Human Resource Studies (CAHRS) Cornell University.

Chiang, F. (2005, September). A critical examination of Hofstede's thesis and its application to international reward management. International Journal of Human Resource Management 16(9):1545:1563.

Claus, L. (2007, March). Employee retention - Best practices in keeping and motivating employees. $B^{2} B: 11$.

Corporate Leadership Council. (1999a). Chapter 2. Understanding Employee Values. Washington DC: Corporate Executive Board.

Corporate Leadership Council. (2002). The Compelling Offer Revisited: Changes in Employee Preferences over time. Washington DC: Corporate Executive Board.

Corporate Leadership Council. (2004). The Effort Dividend - Driving Employee Performance And Retention Through Engagement. Washington DC: Corporate Executive Board.

Corporate Leadership Council. (2005). Total Rewards Philosophy Components and Statements. Washington DC: Corporate Executive Board.

Corporate Leadership Council. (2007). Building and Managing a competitive employment value proposition in the United Kingdom. Washington DC: Corporate Executive Board. 
Corporate Leadership Council. (2008). CLC Quarterly report on HR news and trends. Available from http://www.clc.executiveboard.com. (Accessed on 16 June 2008).

CPP (2008). Myers-Briggs Type Indicator ${ }^{\circledR}$ Assessment (MBT/ $\left.{ }^{\circledR}\right)$. Available from http://www.cpp.com. (Accessed 20 May 2008).

Crawford, N. \& Giowa, T. (2008, May). Getting to the Right Flexrewards program for your organisation. Paper presented at the 2008 Total Rewards WorldatWork Conference and Exhibition, 26 - 29 May 2008, Philadelphia, USA.

Deci, E.L. \& Ryan, R.M. (2000). The what and why of goal pursuits: human needs and selfdetermination of behaviour. Psychological Inquiry 2000, 1(4):227: 268.

Deloitte. (2004). It's 2008: do you know where your talent is. United Kingdom: Deloitte.

Du Toit, G.E., Erasmus, B.J. \& Strydom, J.W. (2007). Introduction to Business management. $7^{\text {th }}$ edition. South Africa: Oxford University press.

DuBrin, A.J. (2005). Fundamentals of Organizational Behaviour. $3^{\text {rd }}$ edition. Canada: Thomson South-Western.

Frank, F.D., Finnegan, R.P., \& Taylor, C.R. (2004, April). The race for talent: retaining and engaging workers in the $21^{\text {st }}$ century. Manpower Planning, April 2004.

Furnham, A. \& Argyle, M. (1998). The Psychology of Money. UK: T.J. International Ltd, Padstow, Cornwall.

Furnham, A. (2003). Personality, Individual Differences and Incentive Schemes. North American Journal of Psychology, 2003, 5(3):325:334.

Gebauer, J. (2009). Towers Perrin Global workforce study, Part 2. Available from http://www.towersperrin.com. (Accessed on 01 February 2009).

Gerhart, B, \& Rynes, S. L. (2003). Compensation: Theory, Evidence and Strategic Implications. California: Sage Publications, Inc.

Giancola, F. (2006a). Making sense of sabbaticals. Workspan, 07/06:3:6. Scottsdale, USA: WorldatWork Press.

Giancola, F. (2006b). The generation gap: more myth than reality. Human Resources planning, 29(4):32:37.

Giancola, F. (2007). Employee engagement: what you need to know. Workspan, 10(07):57:59. Scottsdale, United States: WorldatWork Press.

Giancola, F. (2008). Employee retention efforts. Workspan, 12(08):30:35. Scottsdale, United States: WorldatWork Press.

Grbich, C. (1994). Women as primary breadwinners in families where men are primary caregivers. Journal of Sociology, 30(2):105:118.

Gross, S. E. \& Edelsten, M. (2006). Paying the price of global expansion. Workspan, 09/2006, pp: 42:46. Scottsdale, United States: WorldatWork Press.

Gross, S. E. \& Friedman, H. E. (2007). Creating an effective Total Rewards Strategy: Holistic approach better supports business success. Mercer Human Resources Consulting CD - Your guide to the age of talent. United States.

Gunkel, M. (2006). An exploratory comparison of employees' performance reward preferences in Germany, China, Japan and the USA. DUV. Available from http://www.springerlink.com. (Accessed 14 June 2008). 
Hankin, H. (2005). The New Workforce. USA: AMACOM books.

Harris, S. \& Clements, L. (2007). What's the perceived value of your incentives? Workspan, 02/07:21:25. Scottsdale, United States: WorldatWork Press.

Harvard Business Review. (2001). Harvard Business Review on Compensation. USA: Harvard Business School Press.

Harvard Business Review. (2003). Harvard Business Review on Motivating People. USA: Harvard Business School Press.

Henderson, R.I. (2003). Compensation Management in a Knowledge-based World. $9^{\text {th }}$ Edition. New Jersey: Pearson Education, Inc.

Herman, R.E. \& Gioia, J.L. (2000). How to Become an Employer of Choice. USA: Oakhill Press.

Hill, B. \& Tande, C. (2006). Total rewards - the employment value proposition. Workspan, 10/06:19:22. Scottsdale, United States: WorldatWork Press.

Horwitz, F.M., Browning, V., Jain, H. \& Steenkamp, A.J. (2002). Human resource practices and discrimination in South Africa: overcoming the apartheid legacy. International Journal of Human Resource Management, 13(7):1105:1118.

Jung, C.G. (1971). Psychological Types. (E.C. Hull, Ed.). Princeton, N.J: Princeton University Press. (Original work published in 1923).

Kaliprasad, M. (2006, June). Attracting, retaining and motivating capable people. Cost Engineering, 48(6): 20: 26.

Keenan, D. (May 2004). Employment Law. Accountancy, 1133(1329):126.

Keuch, R.W., Chuang, J., May, J.E \& Sheldrake, N. (2006). What do you call Total Rewards in your organisation? Workspan, 10/06: 38. Scottsdale, United States: WorldatWork Press.

Kroeger, O. \& Thuesen, J.M. (1988). Type Talk. USA: Delacorte Press.

Lawler, E.E. (1990). Strategic pay. San Francisco: Jossey-Bass Publishers.

Lawler, E.E. (2000). Rewarding Excellence. San Francisco: Jossey-Bass Publishers.

Linder, R. (2000). What will I do with my money? USA, Chicago: Northfield Publishing.

Linkow, P. (2006). Winning the competition for talent. Workspan, 10/06: 29:32. Scottsdale, United States: WorldatWork Press.

Locke, E.A. \& Latham, G.P. (2002). Building a practically useful theory of goal setting and task motivation: A 35 year odyssey. American Psychologist, 57:705:717.

MacGrain Herkenhoff, L.M. (2000). Motivational remuneration (pay) preferences: Cultural analysis within the Hofstede model. USA: Dissertation.com.

Manning, J. (2008, April). Managing Flexibility. Training Journal:17: 19.

Martin, J. (2005). Organisational Behaviour and Management. $3^{\text {rd }}$ edition. Italy: G. Canale \& C.

Masarech, M. (2008). Employee engagement in Europe. Workspan, 12/08: 98: 101. Scottsdale, United States: WorldatWork Press. 
Maslow, A.H. (1943). A theory of motivation. Available from http://www.psychclassics.yorku.ca/maslow/motivation.htm. (Accessed 10 September 2009).

McCaulley, M.H. (1998). MBTI® Manual: A guide to the development and use of the Myers-Briggs Type Indicator ${ }^{\circledR}$. $3^{\text {rd }}$ edition. USA: CPP Inc.

Menefee, J.A. \& Murphy, R.O. (2004). Rewarding and retaining the best. Benefits Quarterly, Third Quarter, 2004.

Meulders, D., Plasman, R. \& Rycx, F. (2004). Earnings inequalities: gender, race and sexual orientation. International Journal of Manpower, 25(3/4):244:250.

Milkovich, G.T. \& Newman, J.M. (1999). Compensation. $6^{\text {th }}$ Edition. USA: McGraw-Hill Companies, Inc.

Millner, N. (2008). Individuation: Learning to Live. Available from http://www.mbtitoday.org. (Accessed 24 April 2008).

Mkhehlane, B. (2008, June). Motivation: an inside job. HR Future, 06/2008: 42:43.

Müller, G. \& Plug, E. (2005). Estimating the effect of personality on male-female earnings. Tinbergen Institute Discussion paper, Faculty of Economics, Erasmus University Rotterdam and Tinbergen Institute:1:38.

Murlis, H. (1996). Pay at the crossroads. UK: Institute of Personnel and Development.

Murphy, P. (2008). Motivation and Personality - which Type are you? Available from http://www.sykronix.com (Accessed 25 April 2008).

Myers, I.B. (1998). Introduction to TYPE. $6^{\text {th }}$ edition. USA: CPP, Inc.

Myers, I.B., McCaulley, M.H., Quenk, N.L. \& Hammer, A.L. (1998). $3^{\text {rd }}$ edition. MBTI Manual. USA: CPP, Inc.

Myers, I.B. \& Myers, P.B. (1995). Gifts differing: understanding personality type. USA, California: Davies-Black Publishing.

Nyhus, E.K. \& Pons, E. (2004, September). The effect of personality on earnings. Journal of Economic Psychology, 26 (2005): 363:384.

Olson, M.S., Van Bever, D. \& Verry, S. (2008, March). When growth stall. Harvard Business Review: $50: 61$.

Pallant, J. (2007). SPSS Survival manual. $3^{\text {rd }}$ edition. UK: Bell \& Bain Ltd., Glasgow.

Pearman, R.R. \& Albritton, S.C. (1997). I'm not crazy, I'm just not you - the real meaning of the sixteen personality types. USA: Davies-Black Publishing.

Rehu, M. Lusk, E.J. \& Wolff, B. (2006). Sustainable human resource management in China: a study of a German multinational corporation. World Review of Entrepreneurship, Management and Sustainable Development, 2(1/2): 57:72.

Rehm, B. (2006, November). Learning and employee retention: what's the correlation? Available from http://www.itsinc.net. (Accessed 22 April 2008).

Reinhold, R. (2008). Introduction to Myers-Briggs Personality Type. Available from http://www.personalitypathways.com. (Accessed 24 April 2008).

Robbins, S.P., Odendaal, A. \& Roodt, G. (2003). Organisational Behaviour. South Africa: Creda Communications. 
Schaufeli, W. \& Enzmann, D. (1998). The burnout companion to study and practice. UK: T.J. International Ltd.

Stein, S.J. (2007). Make your workplace great. Canada: John Wiley \& Sons, Ltd.

Stewart, G.L. \& Barrick, M.R. (2004). Four lessons learned from the person-sitated debate: A review and research agenda. Personality and organisation. Mahwah: Lawrence Erlbaum.

Sung, A. \& Todd, E. (2004). Line of sight: moving beyond the catch phrase. Workspan, 10/04:65:69. Scottsdale, United States: WorldatWork Press.

Taylor, N. \& Yiannakis, C. (2007, November). South African MBTI Form M Data Supplement. Jopie van Rooyen \& Partners SA (Pty) Ltd. Johannesburg: JvR Head Office.

Taylor, N \& Yiannakis, C. (2009). South African MBTI Form Q Data Supplement. Jopie van Rooyen \& Partners SA (Pty) Ltd. Johannesburg: JvR Head Office.

Thomas, A. (2002). Employment Equity in South Africa: lessons from the global school. International Journal of Manpower, 23(3): 237 - 255.

Towers Perrin (2007). Using total rewards to build an effective employee value proposition. Available from http://www.towersperrin.com. (Accessed 15 May 2008).

Watson Wyatt 2008/9 WorkUSA report (2008). Employee engagement is crucial in tough economic times. Available from http://www.watsonwyatt.com (Accessed 26 February 2009).

Werhane, W. (2008). Hay Group Insight. Available from http://www.promo.haygroupinsight.com (Accessed 23 June 2008).

Westerman, J.W., Beekun, R.I., Daly, J. \& Vanka, S. (2009). Personality and national culture. Management Research News, 32(8): 767:781.

WorldatWork. (2007). The WorldatWork Handbook of Compensation, Benefits \& Total Rewards. Hoboken, New Jersey: John Wiley \& Sons, Inc.

Zingheim, P.K. \& Schuster, J. R. (2007). High Performance Pay. USA: WorldatWork Press. 